\title{
The Intrathymic Expression of Insulin-related Genes: Implications for Pathophysiology and Prevention of Type 1 Diabetes
}

\author{
Vincent Geenen*, Pierre J. Lefebvre \\ Department of Medicine and Institute of Pathology, University of Liege, Liege, Belgium
}

Summary. Recent experimental work has challenged and shattered the old concept of a sequestration of pancreatic islet antigens from developing T-cells within the thymic environment. There is now compelling evidence that the central immunological tolerance of the whole insulin family may be induced during the process of T-cell ontogeny in the thymus. Transcripts of insulin-like growth factor II (IGF-II), IGF-I and insulin genes have been characterized in human, rat and mouse thymuses. At the peptide level, IGF-II was shown to be the dominant polypeptide of the insulin family in the thymus from different species. Data are presented which support a dual role of thymic IGF-II both in T-cell development as well as in T-cell negative selection. Using animal models of autoimmune diabetes, current research is investigating the hypothesis that a defect of thymic T-cell education to the insulin family is implicated in the pathophysiology of human Type 1 diabetes. An efficient and secure prevention of Type 1 diabetes could be designed on the basis of the strong natural tolerogenic properties of the thymus. (C) 1998 John Wiley \& Sons, Ltd.

\section{INTRODUCTION}

A fundamental property of the immune system is its inability to react against the molecular structure of its host. In other words, before reacting against "non-self" infectious agents, the immune system must be tolerized to the "self". The induction of immune selftolerance is a multi-step process which begins in the thymus during fetal development (central tolerance) and which also involves inactivating or anergizing mechanisms outside the thymus (peripheral tolerance). ${ }^{1}$ It is well established today that the thymus is the primary lymphoid organ involved in the development of competent and self-tolerant T-cells. ${ }^{2}$ From a histophysiological point of view, three types of cells have been described as constituents of the thymic environment which control T-cell differentiation. The predominant stromal cells (around $85 \%$ ) are epithelial cells (TEC) which derive from embryonic endoderm of the $3 \mathrm{rd}$ and 4 th

\footnotetext{
*Correspondence to: Prof. Vincent Geenen, Institute of Pathology CHU-B23, Laboratory of Radio-Immunology, B-4000 Liege, 1 Sart Tilman, Belgium

Contract Grant Sponsors: Juvenile Diabetes Foundation International; Suzanne and Jean Pirart Fund of the Belgian Association of Diabetes; National Fund of Scientific Research (Belgium); Association contre le Cancer (Belgium); Foundation Leon Fredericq (Liege University Medical School)

Key Words: thymic epithelium, insulin self antigens, T-cell development, T-cell tolerance, Type 1 diabetes Received: 3 October 1997; accepted (revised): 13 November 1997

Abbreviations: IGF, insulin-like growth factor; mRNA, messenger RNA; INS, human gene of insulin; IGF2, human gene of IGF-II; Igf2, murine gene of IGF-II; IR, immunoreactive; MHC, major histocompatibility complex; mAb, monoclonal antibody; VNTR, variable number of tandem repeats; PCR, polymerase chain reaction
} 
pharyngeal pouches. The contribution to the thymic epithelium of the ectoderm from the 3rd branchial cleft is still a matter of discussion. Among TEC of the outer cortex, thymic "nurse" cells (TNC) provide a very specialized microenvironment into which 50-150 immature $\mathrm{T}$ cells migrate and differentiate at contact of these large epithelial cells.,4 Bone marrowderived dendritic cells and macrophages represent the remaining components of thymic parenchyme. They are dedicated professional antigen-presenting cells although this property is also shared by TEC/TNC. ${ }^{5}$ The dual physiological role of the thymus in T-cell development and in the negative selection of self-reactive Tcells (by clonal deletion or developmental arrest) remains a paradox hardly explained by the available models. Indeed, it is problematic to understand how two fundamental processes such as T-cell life and death can be mediated through a unique trimolecular complex: the self-antigen, the major histocompatibility complex (MHC)-encoded presenting protein and the $\mathrm{T}$-cell receptor for the antigen (TCR). ${ }^{6,7} \mathrm{On}$ the basis that TEC/TNC from different species express a repertoire of neuroendocrine-related polypeptides, we have proposed a model which recapitulates at the molecular level the dual physiological role of the thymus. Thymic neuroendocrine-related precursors may engage two distinct types of interactions with differentiating T-cells. ${ }^{8,9}$ These precursors are a source of cryptocrine signals which are targetted to the outer surface of TEC/TNC plasma membrane from where they can bind to neuroendocrinetype receptors expressed by contacting thymocytes (pre-T-cells). The same precursors can be processed into neuroendocrine self-antigens which are presented by the thymic MHC system. ${ }^{10,11}$ It is thought that the central T-cell tolerance of neuroendocrine families could be mediated in this way. Neuroendocrine self-antigens usually correspond to peptide sequences which are highly conserved throughout the evolution of their family, and there is experimental evidence, at least for some of them, that their thymic presentation is not restricted in an allelic fashion. ${ }^{12,13}$

\section{HISTORICAL OVERVIEW OF THYMIC INSULIN-LIKE POLYPEPTIDES}

For a long time, an unbreakable frontier was thought to separate pancreatic insulin- secreting islet $\beta$-cells and the developing $\mathrm{T}$ lymphocytes within the thymus. A series of investigations have demonstrated that such a concept is no longer valid and that the $\mathrm{T}$ cell system may be educated during thymic ontogeny to recognize the molecular identity of the pancreatic islet $\beta$-cell, i.e. the endocrine secretion of insulin.

Already by 1965 , on the basis that AKR female mice develop hypoglycaemia and thymic hyperplasia associated with lymphatic leukaemia, Pansky et al. reported the presence of an insulin-like peptide within the thymus from AKR strain mice, as well as from bovine and porcine species. ${ }^{14}$ Mouse thymic extracts induced a marked hypoglycaemic effect when subcutaneously injected into young (3-4 weeks of age) female AKR mice. The biological action of thymic extracts even exceeded that of similarly prepared pancreatic extracts. Important quantities of immunoreactive (IR) insulin (from 150 to $>500 \mu \mathrm{U} / \mathrm{g}$ ) could be extracted from the thymus, in particular with acid-alcohol from beef and pork thymus. Using fluoresceinlabelled guinea-pig anti-beef insulin, fluorescing elements were observed among reticular cells and in Hassall's corpuscles of pig thymus. Interestingly, the authors discussed the agreement of their data with previous studies reporting hypoglycaemia associated with massive tumours of epithelial and mesodermal origin. ${ }^{15,16}$ They also postulated a role for this thymic insulin-like reticular hormone in the initiation of immunological competence and lymphopoiesis.

To our knowledge, this thymic insulin-like reticular biological and IR peptide has not been further characterized. In 1987, however, Han et al. described a wide distribution in human fetal tissues of insulin-like growth factor (IGF) messenger RNA (mRNA) by in situ hybridization with oligonucleotides complementary to portions of human IGF-I and IGF-II. ${ }^{17}$ In the fetal thymus, IGF transcripts were found in the capsule and in interlobular septa with a relative predominance of IGF-II transcripts. No IGF mRNAs could be evidenced in thymocytes. It has to be noted, however, that other authors failed to detect IGF-I mRNA in human fetal tissues. ${ }^{18}$ Through the use of immunocytochemistry, IGF-IR-positive cells were found in the corpuscles and interlobular septa of human fetal thymus. ${ }^{19}$ The positive cells were described as having the morphology of imma- 
ture haematopoietic precursors. Since the antibodies recognized both IGF-I and IGF-II, the identification of specific IGFs was precluded. The relative quantification of IGF transcripts in the human fetal thymus revealed two-fold more IGF-II $\left( \pm 25 \mathrm{pg} / 10 \mu \mathrm{g}\right.$ poly $\left.\mathrm{A}^{+} \mathrm{RNA}\right)$ than IGFI mRNAs $\left( \pm 12 \mathrm{pg} / 10 \mu \mathrm{g}\right.$ poly $\left.\mathrm{A}^{+} \mathrm{RNA}\right){ }_{,}{ }^{20}$ suggesting that IGF-II is synthesized in greater quantities than IGF-I in this organ during embryonic development.

Since central T-cell tolerance of neuroendocrine functions could be induced by the thymic repertoire of neuroendocrine self-antigens, ${ }^{21}$ a series of investigations was initiated in order to identify the dominant member of the insulin family expressed in the thymic microenvironment. Using a panel of specific antibodies directed against several members and epitopes of the insulin family, IR IGFII was clearly identified within TEC of the subcapsular cortex and the medulla of human and rat thymus. ${ }^{22} \mathrm{~A}$ monoclonal antibody $(\mathrm{mAb})$ against human proinsulin ${ }^{23}$ revealed a slight labelling outside thymic lobules, in the interstitial tissue of interlobular septa and the thymic capsule. The staining with mAbs to the C-terminal part of the bovine insulin B chain (OXI-002 and OXI-005, Novo Nordisk) was mainly negative within the thymic stroma, while a slight labelling could be observed in connective components. Some IGF-I-positive cells were also identified in thymic lobules but these cells were not epithelial; their distribution and morphology were similar to macrophages. Further characterization of thymic IR IGF-II confirmed that $\pm 65 \%$ of the immunoreactivity corresponds to recombinant human IGF-II. IR IGF-II was not detected in the supernatant of primary cultures of human TEC, either in basal conditions or after treatment with epidermal growth factor. However, a large part part of IR IGF-II was shown to be associated with TEC membranes. Using specific radioimmunoassays, IGF-II was also shown to be the dominant thymic peptide of the insulin family. In the human thymus, IGF-II, IGF-I and insulin concentrations were respectively $96.7 \pm 10.6 \mathrm{ng} / \mathrm{g}$, $42.9 \pm 5.0 \mathrm{ng} / \mathrm{g}$ and $<0.1 \mathrm{ng} / \mathrm{g}$ wet weight. Using confocal microscopy and immunocytochemistry with specific antibodies, IGF-II (but neither IGF-I nor insulin) was detected at the outer surface of TEC plasma membrane (Achour et al., submitted). IGF-II transcripts have been isolated from whole human thymic extracts, as well as from primary cultures of human TEC. Through the use of polymerase chain reaction (PCR) with different primers, the intrathymic expression of the IGF-II gene was found to be under the control of the same promoters as in other fetal and adult extrahepatic tissues. ${ }^{24,25}$

The effects of IGF-II overexpression were investigated by the generation of transgenic mice carrying one of three different human IGF-II minigenes in which different non-coding exons (exon 5, truncated exon 5 or exon 6) preceded the coding exons 7,8 and 9. The three IGF-II minigenes were placed under the control of the MHC $\mathrm{H}-2 \mathrm{~K}^{\mathrm{b}}$ promoter. The highest levels of IGF-II minigene mRNA expression were detected in lines containing the truncated exon 5 construct. The highest mRNA expression was found in thymus and spleen; serum IGFII levels at 8 weeks of age were increased seven- to eight-fold in homozygous transgenic lines but no significant hypoglycaemia was observed. Among several organs, only the thymus showed a significant increase of weight in these transgenics, in agreement with the high mRNA expression within this organ. ${ }^{26}$ With in situ hybridization, expression of the IGF-II transgene was found with high intensity in the thymic medulla and in the white pulp/marginal zone of the spleen, whereas there were scattered positive cells in the thymic cortex and in the splenic red pulp. Hybridization was restricted to non-lymphocytic cells and immunocytochemistry revealed intense IGF-II peptide staining with the same distribution of IGF-II mRNA. ${ }^{27}$

Going back to the initial observations made by Pansky et al, ${ }^{14}$ there is now ample evidence that the thymic insulin-like reticular factor corresponds in fact to IGF-II. The IGF-II structure closely related to (pro)insulin might explain a cross-reactivity with the antibodies against insulin used at that time. The hypoglycaemic properties of IGF-II have been well described ${ }^{28}$ and might also explain the biological activity of thymic extracts on glucose metabolism. The syndrome of hypoglycaemia and lymphatic leukaemia associated with thymic hyperplasia of some AKR female mice could result from an overexpression of $\operatorname{Igf} 2$ in hyperplasic thymic epithelium, a subsequent secretion of IGF-II 
in the bloodstream, as well as a profoundly disturbed intrathymic lymphopoiesis.

The hypothesis for a central T-cell tolerance of the peripheral pancreatic islets was further supported by the observation that transcripts of insulin, glucagon, somatostatin, pancreatic polypeptide and the $67 \mathrm{kDa}$ isoform of glutamic acid decarboxylase could be detected in the murine thymus using PCR with 30 cycles of amplification. ${ }^{29}$ Thymic insulin gene (INS) expression was strongest in perinatal mice and persisted until 12 weeks of age. Two recent papers confirmed these findings and reported that INS transcripts, as well as (pro)insulin protein, are detected at low levels in the human fetal thymus. Thymic concentrations of insulin IR were $98-1200 \mathrm{fmol} / \mathrm{g}$ wet weight in the first study, ${ }^{30}$ whereas proinsulin concentrations were $1.904 \pm 1.428 \mathrm{SD} \mathrm{pmol} / \mathrm{mg}$ protein and those of insulin were $0.437 \pm 0.218 \mathrm{SD} \mathrm{pmol} / \mathrm{mg}$ protein in the second study. ${ }^{31}$ Since long class III variable number tandem repeat (VNTR) alleles (140-210 repeats) are associated with two- to three-fold higher thymic INS mRNA levels, the authors suggested that the protective effect of these alleles against Type 1 diabetes could be explained by the higher level of thymic INS expression, thereby facilitating the induction of central immunological self-tolerance of insulin. Using in situ hybridization, INS transcripts have been detected in thymic dendritic cells although the protein could not be detected by immunocytochemistry (F. Homo-Delarche, personal communication). The induction of a strong tolerogenic action by thymic (pro)insulin may nevertheless be questioned. Thymic (pro)insulin concentrations are very low and thymic T-cell tolerance rapidly decreases for peptide concentrations below $10 \mathrm{nM}^{32,33}$ In addition, a recent discussion was raised about the precise boundaries of the IDDM2 locus of susceptibility to Type 1 diabetes which could also include two genes close to the INS VNTR, the tyrosine hydroxylase and IGF2. ${ }^{34,35}$ There is also strong evidence that implicates an imprinted gene in the INS-IGF2 region of chromosome 11p15 in the aetiology of Type 1 diabetes. Since INS is not imprinted in the human fetal pancreas, the monoallelic expression of IGF2 in the thymus might explain why insulin-dependent diabetes is transmitted by diabetic fathers more than twice as often as by diabetic mothers. ${ }^{36}$

\section{THE DUAL PHYSIOLOGICAL ROLE OF THYMIC IGF-II}

A functional signalling mediated by IGF-II and IGF receptors is plausible between TEC/TNC and immature T-cells since type 1 and type 2 IGF receptors are detected in rat thymocytes and murine thymoma cells, ${ }^{37}$ on human phytohaemagglutinin (PHA)-activated T-cells and on anti-CD3-activated human Tlymphocytes. ${ }^{38,39}$ Kooijman et al. have described a differential expression of type 1 IGF receptors in relation to the stage of activation and differentiation of human T-lymphocytes. ${ }^{40}$ Interestingly, in IGF-II transgenic mice the increased thymic cellularity is associated with a stimulated generation of phenotypically normal Tcells, in particular $\mathrm{CD}^{+} \mathrm{T}$-cells. ${ }^{41}$ In our hands, specific type 2 IGF receptors were found to be expressed by a murine immature T-cell line as well as by Jurkat T-cells. ${ }^{42}$ By affinity crosslinking, the type 2 IGF receptor expressed by lymphocytes was shown to have a molecular mass $( \pm 260 \mathrm{kDa})$ similar to that found on other cells (Goxe et al., in preparation). On the basis of these observations, thymic IGF-II may thus intervene in a functional cryptocrine signalling between TEC and pre-T-lymphocytes during their intrathymic developmental programme.

As discussed earlier, IGF-II was found to be the dominant member of the insulin hormone family expressed by TEC/TNC from different species. Thymic IGF-II concentrations are high $( \pm 100 \mathrm{ng} / \mathrm{g})$ and it has been shown that the final orientation of an antigen-driven immune response, towards either priming (immunogenic) or tolerizing (tolerogenic), is determined by the dominant T-cell epitopes. ${ }^{43}$ Thus, if a tolerogenic immune response follows the thymic expression of an insulin-related protein, this should firstly concern the dominant thymic peptide of the insulin family. Thymic IGF-II may induce a strong central immune tolerance of IGFs similar to that observed for peripheral proteins resulting from their thymic expression. ${ }^{44}$ The crucial role of IGFs in fetal and postnatal development implies that these proteins have to be protected from an autoimmune attack. As an important though indirect argument for the tolerogenic properties of IGF-II, it is known that the production of specific antibodies is much more difficult with IGF-II than with insulin or IGF-I. ${ }^{45,46}$ The IGF- 
II molecule includes peptide sequences which are highly conserved throughout the evolution of the insulin family. ${ }^{47}$ Because of this close homology, thymic IGF-II would be a good candidate for inducing central immune tolerance of the insulin family although the tolerance of insulin per se would be weaker. This might explain why B- and T-cell autoreactivity to insulin has been equally observed in diabetic and related non-diabetic individuals. ${ }^{48}$

\section{RELATIONSHIPS BETWEEN THE THYMUS AND TYPE 1 DIABETES}

The question of a defective thymic censorship as one element implicated in the pathophysiology of autoimmune diabetes has not been intensively investigated until now. Some elegant studies, however, have provided experimental arguments supporting this idea. Neonatal thymectomy prevents the emergence of diabetes in an animal model of Type 1 diabetes, the Bio-Breeding (BB) rat. ${ }^{49}$ The benefit of thymectomy might in fact result from the removal of a defective organ responsible for the continual release and the peripheral enrichment of intolerant self-reactive T-lymphocytes. Conversely, the occurrence of diabetes is prevented by the transplantation of thymus from diabetesresistant to diabetes-prone $\mathrm{BB}$ rats. ${ }^{50}$ Transplantation of the thymus from NOD mice to

Table I. The dual role of thymic IGF-II in T-cell differentiation

\begin{tabular}{ll}
\hline Cryptocrine signalling & $\begin{array}{l}\text { IGF-II or IGF-II-derived } \\
\text { self-antigen presentation }\end{array}$ \\
\hline $\begin{array}{l}\text { Physiology } \\
\text { Accessory pathway } \\
\text { in T-cell development }\end{array}$ & $\begin{array}{l}\text { Physiology } \\
\text { Central T-cell tolerance of } \\
\text { the insulin family and } \\
\text { islet } \beta \text {-cells }\end{array}$ \\
$\begin{array}{l}\text { Pathophysiology } \\
\text { T-cell lymphomas } \\
\text { Paraneoplasic } \\
\text { hypoglycaemia }\end{array}$ & $\begin{array}{l}\text { Type 1 diabetes } \\
\text { Pharmacology }\end{array}$ \\
$\begin{array}{l}\text { Immunomodulation by } \\
\text { IGF agonists and } \\
\text { antagonists }\end{array}$ & $\begin{array}{l}\text { Pharmacology } \\
\text { Tolerogenic vaccination }\end{array}$ \\
\hline
\end{tabular}

diabetes-resistant mouse strains was also shown to induce diabetes in the recipients. ${ }^{51}$ While bone marrow transplantation is ineffective in autoimmune diseases of MRL/+ mice, thymus transplantation was found to be a crucial factor for their prevention. ${ }^{52}$ An abnormal process of thymic T-cell selection has been suggested on the basis that diabetes-resistant $\mathrm{BB}$ rat thymus contains thymocytes predisposed to autoreactivity. ${ }^{53}$ As another argument for a role of thymic T-cell repertoire selection in the pathogenesis of autoimmune diabetes, grafts of pure thymic epithelium from NOD mouse embryos to newborn C57BL/ 6 athymic mice were shown to induce CD4 and CD8 T-cell-mediated insulitis and sialitis. ${ }^{54}$ At the histological level, a defect in thymic censorship could result from a disorganization in the tissue microenvironment such as the giant perivascular spaces observed in the NOD mouse thymus ${ }^{55}$ and the epithelial defects of $\mathrm{BB}$ rat thymus. ${ }^{56}$ Altogether these observations support the hypothesis that a defective thymic induction of central T-cell tolerance plays a role in the pathophysiology of Type 1 diabetes. IGF IR elution profiles on G75 columns were analysed in thymic extracts from Wistar Furth (WF), diabetes-resistant and diabetes-prone $\mathrm{BB}$ rats. A peak of $>10 \mathrm{ng} / \mathrm{ml}$ was observed in the elution profile of WF thymus extract; a peak around $1.5 \mathrm{ng} / \mathrm{ml}$ was eluted from diabetes-resistant $\mathrm{BB}$ rat thymus extract, while IGF-II concentrations were almost undetectable in the thymus from diabetes-prone BB rats. ${ }^{57}$ These observations strongly suggest at the molecular level that a defect in thymic IGFII-mediated T-cell education might be implicated in the pathogenesis of autoimmune insulin-dependent diabetes.

\section{TOWARDS A TOLEROGENIC FORM OF VACCINATION FOR THE PREVENTION OF TYPE 1 DIABETES?}

Three factors are thought to be implicated in the pathophysiology of Type 1 diabetes. (1) The effector components are CD4 and CD8 autoreactive T-cells which are specifically oriented against the pancreatic islet insulinsecreting $\beta$-cells. These autoreactive T-cells could result from a spontaneous breakdown of T-cell tolerance, either at the central and/or the 
peripheral level. (2) A series of extra- and intraMHC genes have been demonstrated to be related to Type 1 diabetes. Some of these genes probably intervene in the presentation of islet autoantigens to autoreactive T-lymphocytes, but others certainly not. (3) An environmental factor is finally involved and could establish a pathogenetic link between pancreatic islet autoantigens and autoreactive T-cells. The hypothesis of a molecular mimicry between islet autoantigens and microorganisms might intervene at this level and has recently received an interesting experimental support. ${ }^{58}$ The intervention of microbial superantigens has also been proposed to account for the activation of peripheral autoreactive T-cells. ${ }^{59}$ A preventive strategy of Type 1 diabetes can hardly be designed on the basis of the genetic components of the disease or the hazardous external factors. Manipulation of autoreactive T-cells seems to be a more promising way by which an efficient prevention could be designed.

There is now considerable evidence that insulin is one among other autoantigens tackled by various autoreactive components of the immune system in both animal and human Type 1 diabetes. ${ }^{60,61}$ Moreover, insulin is a specific marker of the islet $\beta$-cells. Oral, intranasal and parenteral administration of insulin or insulin-derived dominant autoantigens have been shown to inhibit the occurrence of diabetes in animal models of Type 1 diabetes. ${ }^{62,63}$ However, one cannot exclude the risk of triggering autoimmunity by peripheral administration of an autoantigen. ${ }^{64}$ Reprogramming the immune tolerance which is thought to be broken in autoimmunity represents an attractive srategy for the prevention of devastating autoimmune diseases such as Type 1 diabetes. Such reprogramming could be based on the natural tolerogenic properties of the thymic epithelium. Instead of a classical "vaccination" (with immune activation and induction of "memory" immunocompetent cells), a form of "tolerogenic" vaccination is proposed that would lead to the deletion or the anergy of peripheral autoreactive T-cells. The induction of T-cell tolerance following peptide vaccination has already been obtained with synthetic peptides representing cytotoxic CD8 epitopes of Tcells oriented against tumours or viruses. ${ }^{65} \mathrm{An}$ efficient and non-toxic prevention of Type 1 diabetes, perhaps even its definitive eradication, could depend upon the strategic choice that will be made between either the induction of tolerance to $\beta$-cell-specific autoantigens (such as insulin, glutamic acid decarboxylase, or others) following their parenteral administration, or the exploitation of the natural tolerogenic properties of thymic IGF-II, the self-antigen precursor of the insulin hormone family.

\section{Acknowledgements}

Our studies have been supported by the Juvenile Diabetes Foundation International, the Suzanne and Jean Pirart Fund of the Belgian Association of Diabetes, by the National Fund of Scientific Research (Belgium), by the Association contre le Cancer (Belgium) and by the Foundation Leon Fredericq (Liege University Medical School).

\section{References}

1. Geenen V, and Kroemer G: The multiple ways to cellular immune tolerance. Immunol Today 14: 573-575, 1993.

2. Kruisbeek AM: Development of $a b$ T-cells. Curr Opin Immunol 5: 227-234, 1993.

3. Wekerle H, and Ketelsen UP: Thymic nurse cells: Ia bearing epithelium involved in T lymphocyte differentiation? Nature 283: 402-404, 1980.

4. Geenen V, Defresne MP, Robert F, Legros JJ, Franchimont $\mathrm{P}$, and Boniver $\mathrm{J}$ : The neurohormonal thymic microenvironment: Immunocytochemical evidence that thymic nurse cells are neuroendocrine cells. Neuroendocrinology 47: 365368, 1988 .

5. Lorenz RG, and Allen PM: Thymic cortical epithelial cells can present self-antigens in vivo. Nature 337: 560-562, 1989.

6. Allen PM: Peptides in positive and negative selection: A delicate balance. Cell 76: 593-596, 1994.

7. Ashton-Rickardt PG, and Tonegawa S: A differential-affinity model for T-cell selection. Immunol Today 15: 362-366, 1994.

8. Geenen V, Robert F, Martens H, Benhida A, Degiovanni G, Defresne MP, Boniver J, Legros JJ, Martial J, and Franchimont P: Biosynthesis and paracrine/cryptocrine actions of "self" neurohypophysial-related peptides in the thymus. Mol Cell Endocrinol 76: C27-C31, 1991.

9. Geenen V, Martens H, Robert F, Legros JJ, Defresne MP, Boniver J, Martial J, Lefebvre PJ, and Franchimont P: Thymic cryptocrine signaling and the immune recognition of self neuroendocrine functions. Prog NeuroEndocrinImmun 4: 135142, 1991. 
10. Martens H, Malgrange B, Robert F, Charlet C, De Groote D, Heymann D, Godard A, Soulillou JP, Moonen G, and Geenen V: Cytokine production by human thymic epithelial cells: control by the immune recognition of the neurohypophysial self-antigen. Regul Pept 67: 39-45, 1996.

11. Vanneste $Y$, Ntodou Thome A, Vandersmissen E, Charlet C, Franchimont $D_{x}$ Martens H, Lhiaubet AM, Schimpff RM, Rostene W, and Geenen $\mathrm{V}$ : Identification of neurotensin-related peptides in human thymic epithelial cell membranes and relationship with major histocompatibility complex class I molecules. J Neuroimmunol 76: 161166, 1997.

12. Martens H, Goxe B, and Geenen V: The thymic repertoire of neuroendocrine self antigens: Physiological implications in T-cell life and death. Immunol Today 17: 312-317, 1996.

13. Geenen V, Wiemann M, and Martens H: Thymus gland, neuroendocrine immunology. In Encyclopedia of Neuroscience on CD-ROM, 2nd edn, Adelman G, and Smith BH, Eds. Elsevier, Amsterdam, 1998.

14. Pansky B, House EL, and Cone LA: An insulinlike thymic factor: A preliminary report. Diabetes 14: 325-332, 1965.

15. Silverstein MN, Wakim KG, and Bahn RC: Hypoglycemia associated with neoplasia. Am J Med 36: 415-423, 1964.

16. Doege KW: Fibrosarcoma of the mediastinum. Ann Surg 92: 955-960, 1930.

17. Han VKM, D'Ercole AJ, and Lund PK: Cellular localization of somatomedin (IGF) messenger RNA in the human fetus. Science 236: 193-197, 1987.

18. Scott J, Cowell J, Robertson ME, Priestley LM, Wadley R, Hopkins B, Pritchard J, Bell GI, Rall LB, Graham CF, and Knott TJ: Insulin-like growth factor II gene expression in Wilm's tumour and embryonic tissues. Nature 317: 260 262, 1985.

19. Han VKM, Hill DJ, Strain AJ, Towle AC, Lauder JM, Underwood LE, and D'Ercole AJ: Identification of somatomedin/insulin-like growth factor immunoreactive cells in the human fetus. Pediatr Res 22: 245-249, 1987.

20. Han VKM, Lund PK, Lee DC, and D'Ercole AJ: Expression of somatomedin/insulin-like growth factor messenger ribonucleic acids in the human fetus: Identification, characterization, and tissue distribution. J Clin Endocrinol Metab 66: 422429, 1988.

21. Geenen V, Robert F, Martens H, De Groote D, and Franchimont P: The thymic education of developing $\mathrm{T}$ cells in self neuroendocrine principles. J Endocr Invest 15: 621-629, 1992.

22. Geenen V, Achour I, Robert F, Vandersmissen E, Sodoyez JC, Defresne MP, Boniver J, Lefebvre PJ, and Franchimont P: Evidence that insulinlike growth factor II (IGF-II) is the dominant member of the insulin superfamily. Thymus 21: 115-127, 1993.

23. Sodoyez JC, Koch M, Lemaire I, Sodoyez-Gof- faux F, Rapaille A, François-Gerard C, and Sondag D: Influence of affinity of antibodies upon their detection by liquid phase radiobinding assay and solid phase enzyme-linked immunosorbent assay: Demonstration using monoclonal antibodies raised against rDNA human proinsulin. Diabetologia 34: 463-468, 1991.

24. Kecha O, Achour I, Hodzic D, Goxe B, Winkler $\mathrm{R}$, and Geenen V: IGF-II expression in the human thymus. Proc 10th Intl Congr Endocrinol, abstract P1-659, 1996.

25. Kecha O, Achour I, Martens H, Winkler R, Lefebvre PJ, and Geenen V: Characterization of the insulin-like growth factor (IGF) axis in the human thymus. Proc 79th Ann Meeting Endocr Soc, p. 502 (P3-263), 1997.

26. van Buul-Offers $S C$, de Haan $K$, Reijnen-Gresnigt MG, Meinsma D, Jansen M, Oei SL, Bonte EJ, Sussenbach JS, and Van den Brande JL: Overexpression of human insulin-like growth factorII in transgenic mice causes increased growth of the thymus. J Endocrinol 144: 491-502, 1995.

27. Van der Ven LTM, Roholl PJM, Reijnen-Gresnigt MG, Bloemen RJ, and van Buul-Offers SC: Expression of insulin-like growth factor II (IGFII) and histological changes in the thymus and spleen of transgenic mice overexpressing IGF-II. Histochem Cell Biol 107: 193-203, 1997.

28. Zapf J, Hauri C, Waldvogel M, and Froesch ER: Acute metabolic effects and half-lives of intravenously administered insulin-like growth factors I and II in normal and hypophysectomized rats. J Clin Invest 77: 1768-1775, 1986.

29. Jolicoeur C, Hanahan D, and Smith KM: T-cell tolerance toward a transgenic $\beta$-cell antigen and transcription of endogenous pancreatic genes in thymus. Proc Natl Acad Sci USA 91: 6707-6711, 1994.

30. Vafiadis P, Bennett ST, Todd JA, Nadeau J, Grabs R, Goodyer CG, Wickramasinghe S, Colle E, and Polychronakos C: Insulin expression in human thymus is modulated by INS VNTR alleles at the IDDM2 locus. Nature Genet 15: 289-292, 1997.

31. Pugliese AA, Zeller M, Fernandez Jr A, Zalcberg LJ, Bartlett RJ, Ricordi C, Pietropaolo M, Eisenbarth GS, Bennett SJ, and Patel DD: The insulin gene is transcribed in the human thymus and transcription levels correlate with allelic variation at INS VNTR-IDDM2 susceptibility locus for Type 1 diabetes. Nature Genet 15: 293-297, 1997.

32. Murphy KM, Heimberger A, and Loh DY: Induction by antigen of intrathymic apoptosis of $\mathrm{CD}^{+}$ $\mathrm{CD}^{+}$TCRlo thymocytes in vivo. Science 250: 1720-1723, 1990.

33. Ashton-Rickardt PG, Bandeira A, Delaney JR, Van Kaer L, Pircher HP, Zinkernagel RM, and Tonegawa S: Evidence for a differential avidity model of T-cell selection in the thymus. Cell 76: 651-663, 1994.

34. Doria A, Lee J, Warram JH, and Krolewski AS: Diabetes susceptibility at IDDM2 cannot be positively mapped to the VNTR locus of the insulin gene. Diabetologia 39: 594-599, 1996. 
35. Julier C, Hyer RN, Davies J, Merlin F, Soularue P, Briant L, Cathelineau G, Deschamps I, Rotter JI, Froguel P, Boitard C, Bell JI, and Lathrop GM: Insulin-IGF2 region on chromosome 11p encodes a gene implicated in HLA-DR4-dependent diabetes susceptibility. Nature 354: 155159, 1991.

36. Polychronakos C, Giannoukakis N, and Deal CL: Imprinting of IGF2, insulin-dependent diabetes, immune function, and apoptosis: A hypothesis. Dev Genet 17: 253-262, 1995.

37. Verland S, and Gammeltoft S: Functional receptors for insulin-like growth factors I and II in rat thymocytes and mouse thymoma cells. Mol Cell Endocrinol 67: 207-216, 1989.

38. Kozak RW, Haskell JF, Greenstein LA, Rechler MM, Waldmann TA, and Nissley SP: Type 1 and 2 insulin-like growth factor receptors on human phytohemagglutinin-activated T lymphocytes. Cell Immunol 109: 318-331, 1987.

39. Johnson EW, Jones LA, and Kozak RW: Expression and function of insulin-like growth factor receptors on anti-CD3-activated human $\mathrm{T}$ lymphocytes. J Immunol 148: 63-71, 1992.

40. Kooijman R, Scholtens LE, Rijkers GT, and Zegers BJM: Differential expression of type 1 insulinlike growth factor receptors in different stages of human T cells. Eur J Immunol 25: 931-935, 1995.

41. Kooijman R, van Buul-Offers SC, Scholtens LE, Schuurman HJ, Van den Brande JL, and Zegers BJM: $\mathrm{T}$ cell development in insulin-like growth factor-II transgenic mice. J Immunol 154: 57365745, 1995.

42. Goxe B, Martens H, Vandersmissen E, Achour I, Kecha $\mathrm{O}$, and Geenen V: Interactions entre les cellules $\mathrm{T}$ et la famille insulinique: Etude du recepteur de l'IGF-II. Ann Endocrinol 56: 399, 1995.

43. Sercarz EE, Lehmann PV, Ametani A, Benichou G, Miller A, and Moudgil K: Dominance and crypticity of T-cell antigenic determinants. Annu Rev Immunol 11: 729-766, 1993.

44. Antonia SJ, Geiger T, Miller J, and Flavell RA: Mechanisms of immune tolerance induction through the thymic expression of a peripheral tissue-specific protein. Int Immunol 7: 715-725, 1995.

45. Zapf J, Walter H, and Froesch ER: Radioimmunological determination of insulin-like growth factors I and II in normal subjects and in patients with growth disorders and extrapancreatic tumor hypoglycemia. J Clin Invest 68: 1321-1330, 1981.

46. Enberg G, and Hall K: Immunoreactive IGF-II in serum of healthy subjects and patients with growth hormone disturbances and uraemia. Acta Endocrinol 107: 164-170, 1984.

47. Chan SJ, Cao QP, and Steiner DF: Evolution of the insulin superfamily: Cloning of a hybrid insulin/insulin-like growth factor cDNA from amphioxus. Proc Natl Acad Sci USA 87: 93199323, 1990.

48. Naquet P, Ellis J, Tibensky D, Kenshole A, Singh B, Hodges R, and Delovitch TL: T cell autoreac- tivity to insulin in diabetic and related nondiabetic individuals. J Immunol 140: 2569-2578, 1988.

49. Like AA, Kislaukis E, Williams RM, and Rossini AA: Neonatal thymectomy prevents spontaneous diabetes mellitus in the BB:W rat. Science 216: 644-646, 1982.

50. Georgiou HM, and Bellgrau D: Thymus transplantation and disease prevention in the diabetes-prone Bio-Breeding rat. I Immunol 142: 3400-3405, 1989.

51. Georgiou HM, and Mandel TE: Induction of insulitis in athymic (nude) mice. The effect of NOD thymus and pancreas transplantation. Diabetes 44: 49-59, 1995.

52. Hosaka N, Nose M, Kyogoku M, Nagata N, Miyashima S, Good RA, and Ikehara S: Thymus transplantation, a critical factor for correction of autoimmune disease in aging MRL/+ mice. Proc Natl Acad Sci USA 93: 8558-8562, 1996.

53. Whalen BJ, Rossini AA, Mordes JP, and Greiner DL: DR-BB rat thymus contains thymocyte populations predisposed to autoreactivity. Diabetes 44 : 963-967, 1995.

54. Thomas-Vaslin V, Damotte D, Coltey M, Le Douarin NM, Coutinho A, and Salaun J: Abnormal $\mathrm{T}$ cell selection on nod thymic epithelium is sufficient to induce autoimmune manifestations in C57BL/6 athymic nude mice. Proc Natl Acad Sci USA 94: 4598-4603, 1997.

55. Savino W, Carnaud C, Luan JJ, Bach JF, and Dardenne M: Characterization of the extracellular matrix-containing giant perivascular spaces in the NOD mouse thymus. Diabetes 42: 134-140, 1993.

56. Doukas J, Mordes JP, Swymer C, Niedzwiecki D, Mason R, Rozing J, Rossini AA, and Greiner DL: Thymic epithelial defects and predisposition to autoimmune disease in BB rats. Am J Pathol 145: 1517-1525, 1994.

57. Geenen V, Achour. I, Kecha O, Greiner DL, Rossini AA, and Lefebvre PJ: Thymic insulin-like growth factors (IGFs) in man and in an animal model of autoimmune IDDM. Diabetologia 39 (suppl. 1): A15, 1996.

58. Atkinson MA, and Mclaren NK: The pathogenesis of insulin-dependent diabetes mellitus. $N$ Engl J Med 331: 1428-1436, 1994.

59. Conrad B, Weidmann E, Trucco G, Rudert WA, Behboo R, Ricordi C, Rodriquez-Rilo H, Finegold $\mathrm{D}$, and Trucco M: Evidence for superantigen involvement in insulin-dependent diabetes mellitus aetiology. Nature 371: 351-355, 1994.

60. Simone EA, Yu L, Wegmann DR, and Eisenbarth GS: T cell receptor gene polymorphisms associated with anti-insulin, autoimmune $\mathrm{T}$ cells in diabetes-prone NOD mice. I Autoimmun 10: 317321, 1997.

61. Daniel D, Gill RG, Schloot N, and Wegmann D: Epitope specificity, cytokine production profile and diabetogenic activity of insulin-specific $\mathrm{T}$ cell clones isolated from NOD mice. Eur J Immunol 25: 1056-1062, 1995.

Diabetes Metab. Rev. 14, 95-103 (1998) 
62. Zhang ZJ, Davidson L, Eisenbarth G, and Weiner HL: Suppression of diabetes in nonobese diabetic mice by oral administration of porcine insulin. Proc Natl Acad Sci USA 88: 10252-10256, 1991.

63. Daniel D, and Wegmann DR: Protection of nonobese diabetic mice from diabetes by intranasal or subcutaneous administration of insulin peptide B-(9-23). Proc Natl Acad Sci USA 93: 956960, 1996.
64. Blanas E, Carbone FR, Allison J, Miller JFAP, and Heath WR: Induction of autoimmune diabetes by oral administration of autoantigen. Science 274: 1707-1709, 1996.

65. Toes RM, Offringa R, Blom RJJ, Melief CJM, and Kast WM: Peptide vaccination can lead to enhanced tumor growth through specific T-cell tolerance induction. Proc Natl Acad Sci USA 93: 7855-7860, 1996. 